\title{
First record of Phytopythium sp. causing root and stem rot on Catharanthus roseus in Thailand
}

\author{
Intaparn $\mathbf{P}^{1}$, Noireung $\mathbf{P}^{\mathbf{1}}$, Maumoon $\mathbf{R}^{\mathbf{1}}$, Poti $\mathbf{T}^{\mathbf{1}}$, Wongwan $\mathbf{T}^{\mathbf{1}}$, McGovern $\mathbf{R} \mathbf{J}^{\mathbf{1}}$, \\ Unartngam $\mathbf{J}^{2}$, Tapingkae $\mathrm{T}^{3}$ and To-anun $\mathrm{C}^{1 *}$ \\ ${ }^{1}$ Department of Entomology and Plant Pathology, Faculty of Agriculture, Chiang Mai University, Chiang Mai, \\ Thailand \\ ${ }^{2}$ Department of Plant Pathology, Faculty of Agriculture, Kasetsart University Kamphaeng Saen Campus, Thailand \\ ${ }^{3}$ Mushroom Research and Development Center, Chiang Mai, Thailand
}

Intaparn P, Noireung P, Maumoon R, Poti T, Wongwan T, McGovern RJ, Unartngam J, Tapingkae T, To-anun C 2020 - First record of Phytopythium sp. causing root and stem rot on Catharanthus roseus in Thailand. Plant Pathology \& Quarantine 10(1), 10-20, Doi 10.5943/ppq/10/1/2

\begin{abstract}
During August to October 2019, Catharanthus roseus plants with root and stem rot symptoms were collected from a greenhouse which belongs to farmers in Chiang Mai, Thailand. The causal agent was isolated from the roots and rhizosphere soil of $C$. roseus showing symptoms of root and stem rot disease in plantation areas in Chiang Mai, Thailand. The pathogen was studied by morphological characteristics and molecular analysis based on the internal transcribed spacer (ITS) region it was determined to be Phytopythuim sp. The pathogenicity of the isolate was tested by inoculating detached $C$. roseus leaves with an agar disc containing mycelium of the fungus compared with a sterile agar disc as the control. It was found that Phytopythium sp. isolate MCRCPp021 infected the C. roseus leaves causing a brown rot. Moreover, Phytopythium sp. MCRCPp021 infected and caused rot symptoms on plant crowns in $14 \mathrm{~d}$ after inoculation with a mycelial suspension. This research finding is the first record of Phytopythium sp. MCRC-Pp021 causing root and stem rot of $C$. roseus in Thailand. In addition, in a fungicide test, it was shown that dimethomorph and phosphorous acid were less effective against Phytopythium sp. MCRC-Pp021 at the recommended rate than mancozeb, propineb, thiram, fosetyl-aluminium, tridemorph and metalaxyl which exhibited high efficacy.
\end{abstract}

Key words - morphological characters - pathogenicity - phylogeny - poison food assay - vinca

\section{Introduction}

The genus Phytopythium ( $\mathrm{Pp}$ ) in the family Pythiaceae, order Peronosporales is a recently described genus comprising the species formerly classified in Pythium phylogenetic clade K (Bala et al. 2010, de Cock et al. 2015). The common features of this genus are phytophthora-like ovoid to globose sporangia with papillae, internal proliferation, and pythium-like zoospore discharge, which differentiates this genus from the closely related genera Pythium and Phytophthora (Bala et al. 2010).

Phytopythium is an important genus in agricultural production and several species, such as Phytopythium sp. was reported to cause diseases on Cassava in Brazil (Boari et al. 2018). Pp. helicoides and Pp. vexans which is most frequent in tropical and subtropical regions, is a well- 
known plant pathogen that has been reported to cause leaf, stem, root and crown rot, damping off and leaf blight in several host plants worldwide (Kageyama et al. 2002, Chellemi et al. 2000, Guha \& Hong 2008, Tsukiboshi et al. 2007, Watanabe et al. 2007, Yang et al. 2013, Hong \& Moorman 2005, Tao et al. 2011, Kageyama 2014).

Catharanthus roseus, also known as Vinca or Madagascar periwinkle, is a flowering potted plant that has become very popular. Growing 25 to $41 \mathrm{~cm}$ tall, with dark green leaves and five-petal blossoms in pink, mauve or white, these plants were rapidly adopted especially in the nursery trade. There are several diseases that can cause vincas to wilt, including Phytophthora stem blight and root rot, Pythium root rot, Rhizoctonia stem (Rhizoctonia solani) and root rot, gray mold and the tomato spotted wilt. Phytophthora parasitica, a soilborne fungus, causes serious losses and death in periwinkle with reports from India and the United States. Symptoms of these diseases include dark colored lesions on the stems and branches, yellowing leaves with stunted growth, spots on the foliage, gray mold on the plant or black concentric rings on the leaves (McMillan \& Garofalo 2004). Moreover, Fusarium root rot has been reported from Taiwan (Chung et al. 1998). Blight caused by $P$. nicotianae (syn. $=P$. parasitica) is one of the most damaging diseases of plants in Florida. Other known blights include twig blight caused by Colletotrichum dematium in Florida, foliar blight brought about by P. tropicalis in Virginia (Hao et al. 2010), and gray mold blight caused by Botrytis cinerea in the United States, Italy, and Taiwan (Garibaldi et al. 2009). In addition, previous research in Thailand it was found that $P$. deliense causing root and crown rot on Catharanthus roseus (Intaparn et al. 2019). Many of these diseases and fungal pathogens are prevalent in soil that has poor drainage or gardens that have been over-watered. Chemical compounds are commonly used to control plant diseases, but their incorrect use has favored the development of pathogens resistant to fungicides, and resulted in non-target effects. In the present study, our objectives were to identify the causal agent of root and stem rot in C. roseus and pathogen sensitivity to fungicides

\section{Materials \& Methods}

\section{Isolation and Identification of Pathogens}

Isolation of pathogen was carried out by using a baiting technique. The soil samples were put in sterilized Petri dishes and sterile distilled water (SDW) was poured over the soil to a level of 4-5 $\mathrm{mm}$. Thereafter, fleshy leaves of $C$. roseus were cut in $5 \times 5 \mathrm{~mm}$ pieces, then surface disinfected by immersing in 10\% sodium hypochlorite (Clorox), and rinsed with SDW. Ten leaf discs were then put into each Petri dish containing soil samples. The baiting plates were incubated at room temperature $\left(27-30^{\circ} \mathrm{C}\right)$ for 2 to $3 \mathrm{~d}$. The mycelium was picked out and transferred to plates containing water agar (WA) which were incubated at room temperature. Finally, the hyphal tips were transferred to potato dextrose agar (PDA) to get pure cultures. The colony growth was also periodically examined under a stereomicroscope and fungal structures, e.g. sporangia and oospores, were examined with a compound microscope. The assessment of growth rates for the isolates was conducted on PDA, V8 agar (V8A) and Potato-Carrot agar (PCA) (Van der Plaats-Niterink 1981) in $90 \mathrm{~mm}$ petri dishes incubated at room temperature $\left(25-28^{\circ} \mathrm{C}\right)$. Hyphal growth was recorded every $24 \mathrm{hr}$ for $3 \mathrm{~d}$. Moreover, the growing fungus on PDA was also cut into small piece and put into SDW in Petri dishes and incubated overnight at room temperature to observe sporangia and zoospores. Pure cultures were kept in PDA slants for stock cultures and for further experiments. Isolates were identified by comparing colony growth patterns and morphological features: sporangia, oogonia, antheridia, hyphae and zoospores using genus and species descriptions reported in the literature (Erwin \& Ribeiro 1996).

\section{Molecular Studies}

\section{DNA Extraction and Sequencing}

Mycelia of the Phythopythium isolates harvested from liquid culture were used and DNA 
extraction was done by the CTAB method modified by Weising et al. (2000). The ITS region was amplified using universal primers ITS5 (5'-GGAAGTAAAAGTCGTAACAAGG-3') and ITS4 (5'-TCCTCCGCTTATTGATATGC-3') (White et al. 1990). Amplification was done with the following temperature cycling parameters: denaturation at $95^{\circ} \mathrm{C}$ for $3 \mathrm{~min}$ for the first cycle and $30 \mathrm{sec}$ each for subsequent cycles, annealing for $1 \mathrm{~min}$ at $55^{\circ} \mathrm{C}$, and elongation for $1 \mathrm{~min}$ at $72^{\circ} \mathrm{C}$. The purified PCR products were sent for sequencing by Biogenomed Co., Ltd. ITS rDNA sequences of the pathogenic fungi were aligned with reference sequences of Phytopythium sp. and the dataset was analysed by MEGA7 using Neighbour-joining (NJ) parameters and bootstrap values with 1,000 replicates (Saitou \& Nei 1987).

\section{Pathogenicity Test}

The pathogenicity test was carried out by using Koch's postulates to confirm the pathogenic isolates (Agrios 1997). The tests were carried out with the detached leaf method.

Pathogenicity test was carried out as described by Soytong et al. (2005) with some modifications. One-month-old $C$. roseus leaves were used for the assessment of pathogenicity. For each isolate, healthy $C$. roseus leaves of approximately the same age (the same position on the plant) were collected, clipped at the base and apex, and surface-sterilized by soaking in $10 \%$ Clorox for $3 \mathrm{~min}$ and rinsed 3 times with SDW, and then each leaf was wounded with a syringe needle (5 stabs in each wound site). Then, agar culture discs $(0.5 \mathrm{~cm}$ diameter $)$ containing mycelium of the growing pathogen were cut by cork borer, and placed onto the wounded leaf surface and incubated in a moist chamber at room temperature $(27-30 \mathrm{C})$ for $3 \mathrm{~d}$. The non-inoculated leaves were treated with sterile agar discs and served as controls. The lesion diameter was recorded and confirmed by re-isolation after $3 \mathrm{~d}$ of incubation.

Root inoculation was involved for a secondary pathogenicity test. The inoculum was prepared following the method of Shang et al. (1999). The seven-day-old culture of the pathogen was flooded with sterile distilled water for $2 \mathrm{~d}$ and sterilized glass spreader was used to wipe the culture surface to release the sporangia into sterile water. Finally, the inoculum suspension was adjusted at $1 \times 10^{6}$ zoospores $/ \mathrm{ml}$. The bare roots were prepared by taking out the whole healthy plants of C. roseus from soils. The roots were washed with tap water and dipped in the suspension. Then the test plants were replanted in plastic nursery bags containing sterile soil and maintained in greenhouse until the disease occurs. Then, the whole plants were taken out again. Four replicates were observed and compared with non-inoculated controls.

The Disease Index (DI) was determined as follows: Level $1=$ healthy, green leaves (normal and non-aggressive), Level 2 = pale green, Level 3 = yellow leaves, Level 4 = pale brown (moderately aggressive), Level $5=$ dark brown (highly aggressive). The virulence of isolates was detemined according to disease index (DI).

\section{Fungicide Testing}

The Poison Food Technique (Nene \& Thapliyal 1979) was used to test the in vitro efficacy of different concentrations of five systemic fungicides and three contact fungicides $(0,100,500$, 1,000, 1,500 and 2,000 ppm). Different quantities of fungicides were mixed with PDA. Based on active ingredient, the requisite quantity of the test fungicide was calculated, thoroughly mixed separately, autoclaved and cooled $\left(40^{\circ} \mathrm{C}\right)$, and mixed with PDA in conical flasks to obtain the desired concentrations. This PDA medium amended separately with the test fungicides was then poured (15 $\mathrm{ml} /$ plate) aseptically into Petri plates $(90 \mathrm{~mm}$ dia.) and allowed to solidify at room temperature. A Completely Randomized Design (CRD) was used for the experiment, with three replications. Uniform inoculum size of pathogen was placed in the centre of petri plates containing the poison PDA. Petri plates filled with plain PDA (without any fungicide) were inoculated with a pure culture disc of Phytopythium sp. MCRC-Pp021 and maintained as the non-treated control. The petri plates were kept at room temperature and mycelial growth was monitored. Radial mycelial growth/colony diameter were recorded at an interval of $24 \mathrm{~h}$ and continued till the non-treated control plates were fully covered. Mycelial growth inhibition of the test pathogen was calculated by 
applying the formula of Vincent (1947) (see below). Data were recorded by measuring colony diameter $(\mathrm{mm})$ after incubation.

Table 1 Fungicides tested to control mycelial growth of Phytopythium sp. causing root and stem rot on Catharanthus roseus.

\begin{tabular}{|c|c|c|c|c|c|}
\hline No. & Active ingredient & $\begin{array}{l}\text { Trade/ } \\
\text { product name }\end{array}$ & Fungicide group & Form & Type \\
\hline 1 & mancozeb & Mancozeb & Dithiocarbamates & Wettable powder & Contact \\
\hline 2 & propineb & Antracol & Dithiocarbamates & Wettable powder & Contact \\
\hline 3 & thiram & Thianozan & Dithiocarbamates & Wettable granule & Contact \\
\hline 4 & dimethomorph & Forum & $\begin{array}{l}\text { dinnamic acid } \\
\text { amides }\end{array}$ & Wettable powder & Systemic \\
\hline 5 & $\begin{array}{l}\text { fosetyl- } \\
\text { aluminium }\end{array}$ & Aliette & ethylphosphonates & Wettable granule & Systemic \\
\hline 6 & phosphorous acid & Foli- r- fos & Phosphonates & $\begin{array}{l}\text { Emulsifiable } \\
\text { concentrate }\end{array}$ & Systemic \\
\hline 7 & tridemorph & Calixin & $\begin{array}{l}\text { carboxylic acid } \\
\text { amide }\end{array}$ & $\begin{array}{l}\text { Emulsifiable } \\
\text { concentrate }\end{array}$ & Systemic \\
\hline 8 & metalaxyl & Metalaxyl & Acylalanines & Wettable powder & Systemic \\
\hline
\end{tabular}

Radial growths of the pathogen was used for calculating percent growth inhibition according to the formula:

$$
\text { Percent inhibition of radial growth }(\% \mathrm{PIRG})=\frac{\mathrm{R} 1-\mathrm{R} 2}{\mathrm{R} 1} \times 100
$$

Where

$\mathrm{R} 1=$ radial growth of control $(\mathrm{mm})$

$\mathrm{R} 2=$ radial growth of treatments $(\mathrm{mm})$

\section{Results}

\section{Isolation and Morphological Identification}

Symptoms of diseased plants included yellowing and scorching of leaves, poor growth and stunting of plants, dark brown to black lesions on stems and branches, wilting and death. Plants with root rot had reduced root systems and the cortex of individual roots tended to slough off leaving the inner stele behind. (Fig. 1).

Colony characteristics of Phytopythium sp. MCRC-Pp021 included profuse white cottony growth on PDA in a mixed chrysanthemum and rosette pattern, a chrysanthemum pattern on PCA and no special pattern on V8A (Fig. 2).

Mycelium was hyaline, well branched, and the main hyphae up to $5 \mu \mathrm{m}$ wide, dendroid, and often with short side-branches. Simple sympodia (Fig. 3A) were produced rarely in grass leaf blade cultures. Sporangia were ovoid to globose, terminal, papillate, proliferating internally, and 8.8-14.1 $\times 8.9-14.8 \mu \mathrm{m}$ (Fig. 3B). Papillae may develop into discharge tubes (Fig. 3C-F). The zoospore discharge is Pythium-like: the cytoplasm flows out of the sporangium through a discharge tube to form a cytoplasm-filled vesicle at the tip (Fig. 3G). The vesicles generally contained $\sim 25$ zoospores and the zoospores were $2.5-3 \mu \mathrm{m}$ in diameter (Figure $3 \mathrm{H}$ ). The sporangia proliferated internally 
(Fig. 3I, J). The isolates were tentatively identified as Phytopythium sp. based on the morphological characteristics descriptions in Van der Plaats-Niterink (1981) and Bala et al. (2010).

\section{Phylogenetic Analyses}

\section{Amplification and characterization of the rDNA ITS sequences}

PCR amplification of the rDNA ITS region of Phytopythium isolates using the ITS5-ITS4 primer pairs was successful and gave PCR products of 871 base pairs (bp). The isolate MCRCPp021 was identified as Phytopythium sp. based on molecular analysis, corroborating the above morphological identification, BLAST analysis of this isolate revealed $100 \%$ identity with reference sequences of Phytopythium sp. D37 in the GenBank.

The DNA sequences were analyzed for phylogenetic relationships using MEGA 7 software. Bootstrap analysis was performed with 1,000 replications to determine the support for each group. The phylogenetic tree shows that the isolate MCRC-Pp021 was well embedded within comparative Phytopythium sp. isolates with string support at 100\%. (Fig. 4)

\section{Pathogenicity Tests}

In the detached leaf pathogenicity test, Phytopythium sp. isolate MCRC-Pp021 caused brown lesions (mean of $15.5 \mathrm{~mm}$ ) on C. roseus leaves after $33 \mathrm{hr}$. Control leaves remained healthy and showed no symptoms. Moreover, the plants inoculated with the mycelial suspension of Phytopythium sp. showed dark brown lesions on stems and branches, and wilt symptoms in $7 \mathrm{~d}$. Symptoms of root rot included yellowing and scorching of leaves, poor growth and stunting of plants, wilting and death in $14 \mathrm{~d}$. Moreover, plants with root rot had reduced root systems and the cortex of individual roots tended to slough off leaving the inner stele behind. (Fig. 5)

\section{Fungicide Testing}

In poison food assays, mancozeb, propineb, thiram and tridemorph were the most effective in inhibiting mycelial growth of Phytopythium sp. isolate MCRC-Pp021 (Table 2). Mancozeb, propineb, thiram and tridemorph caused $100 \%$ mycelial growth inhibition at all concentrations tested (100, 500, 1000, 1500 and 2000 ppm).
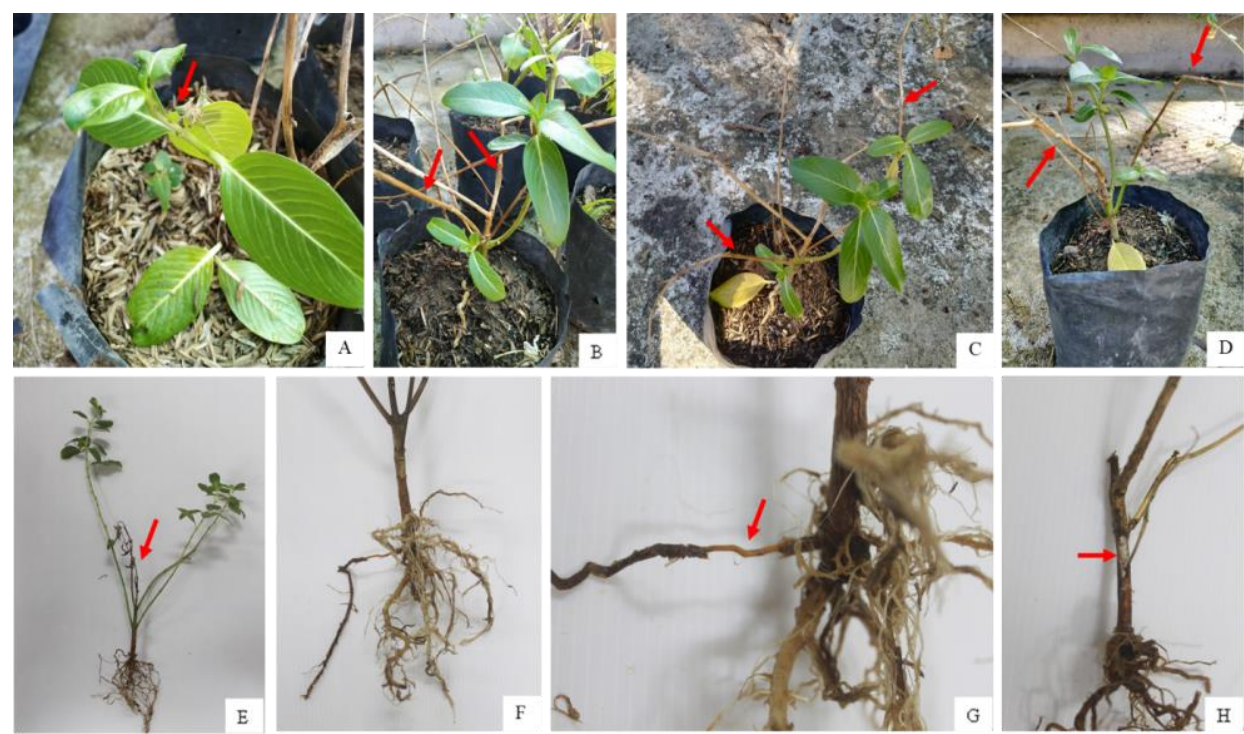

Fig. 1 - Symptoms of root and stem rot associated with Pp. helicoides on Catharanthus roseus seedlings in the nursery. (A-B) stem rot, crown rot and falling leaves, (C) progressively dying scions on living rootstocks, (D-E) dead plants in a later stage, (F-G) root rot in plant showing orange discolouration of the crown area and rotted roots and root tips $(\mathrm{H})$ aerial mycelia on the diseased stems. Arrows indicated lesions (A, B), diseased plants $(\mathrm{C}-\mathrm{F})$ or aerial mycelia $(\mathrm{H})$ 

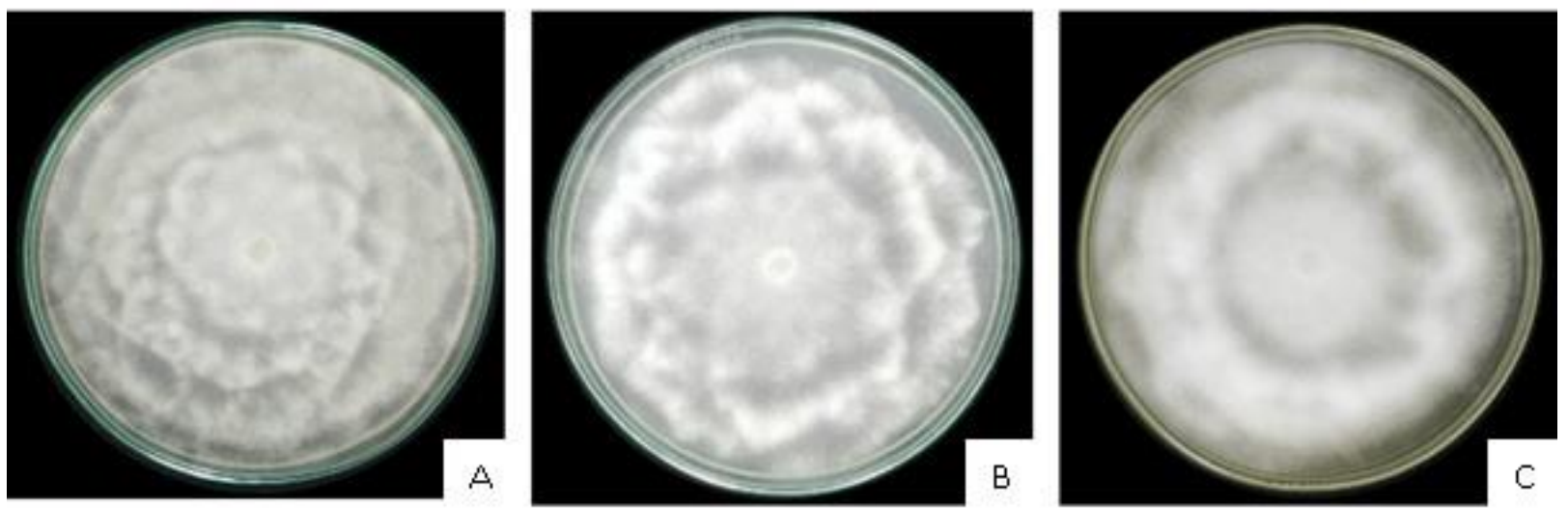

Fig. 2 - Colony morphology of Phytopythium sp. isolate MCRC-Pp021 on (A) PDA, (B) PCA, and (C) V8A
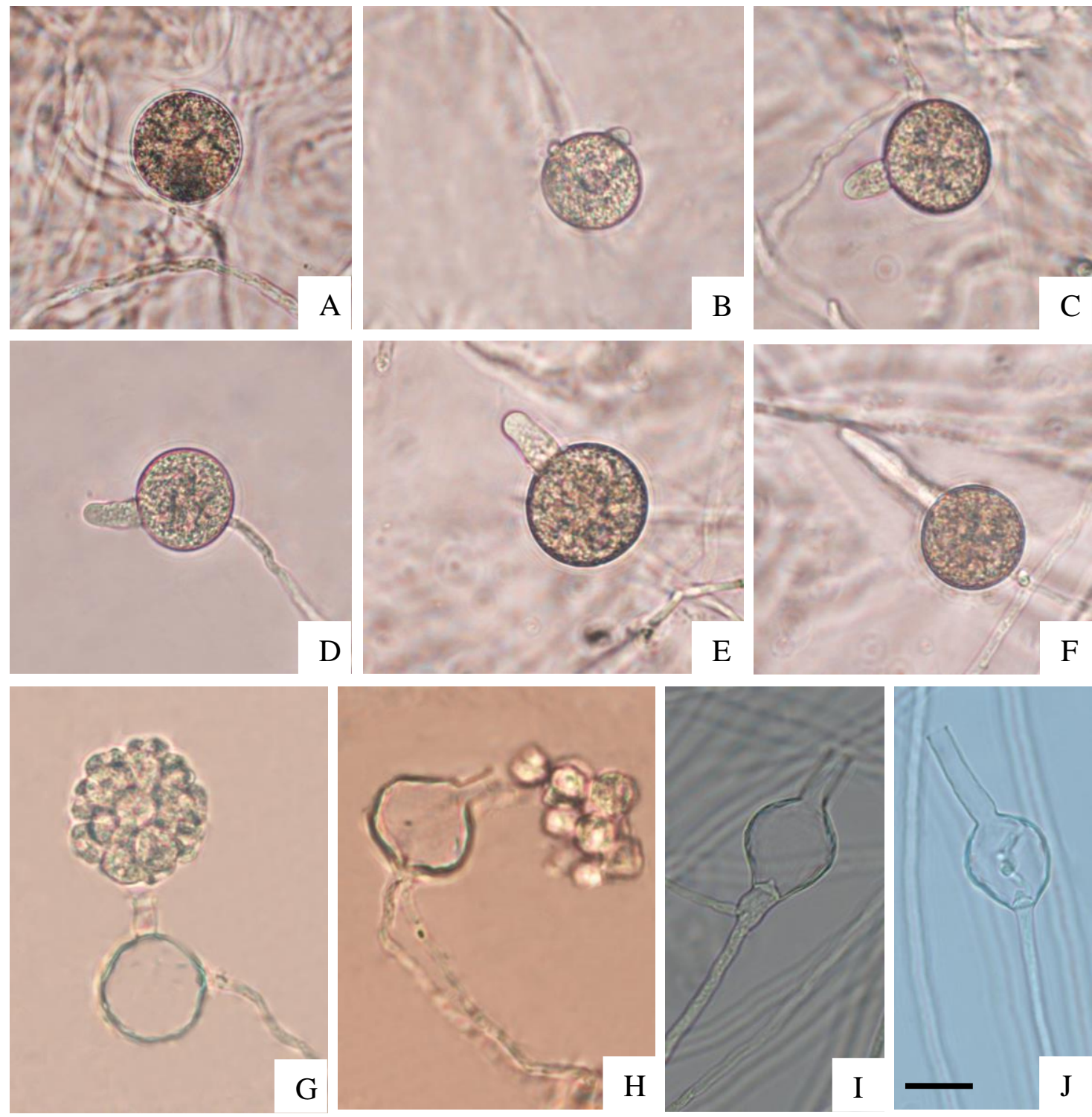

Fig. 3 - Morphological characteristics of Phytopythium sp. Asexual structures of Phytopythium sp. MCRC-Pp021 in water: A Simple sympodia. B Sporangium with two papillae. C, D Pyriform sporangia. E, F Outgrowing papilla. G Sporangium vesicle with zoospores. H Zoospore releasing from vesicle. I, J Empty sporangia with internal proliferation. Scale bar $=10 \mu \mathrm{m}$. 


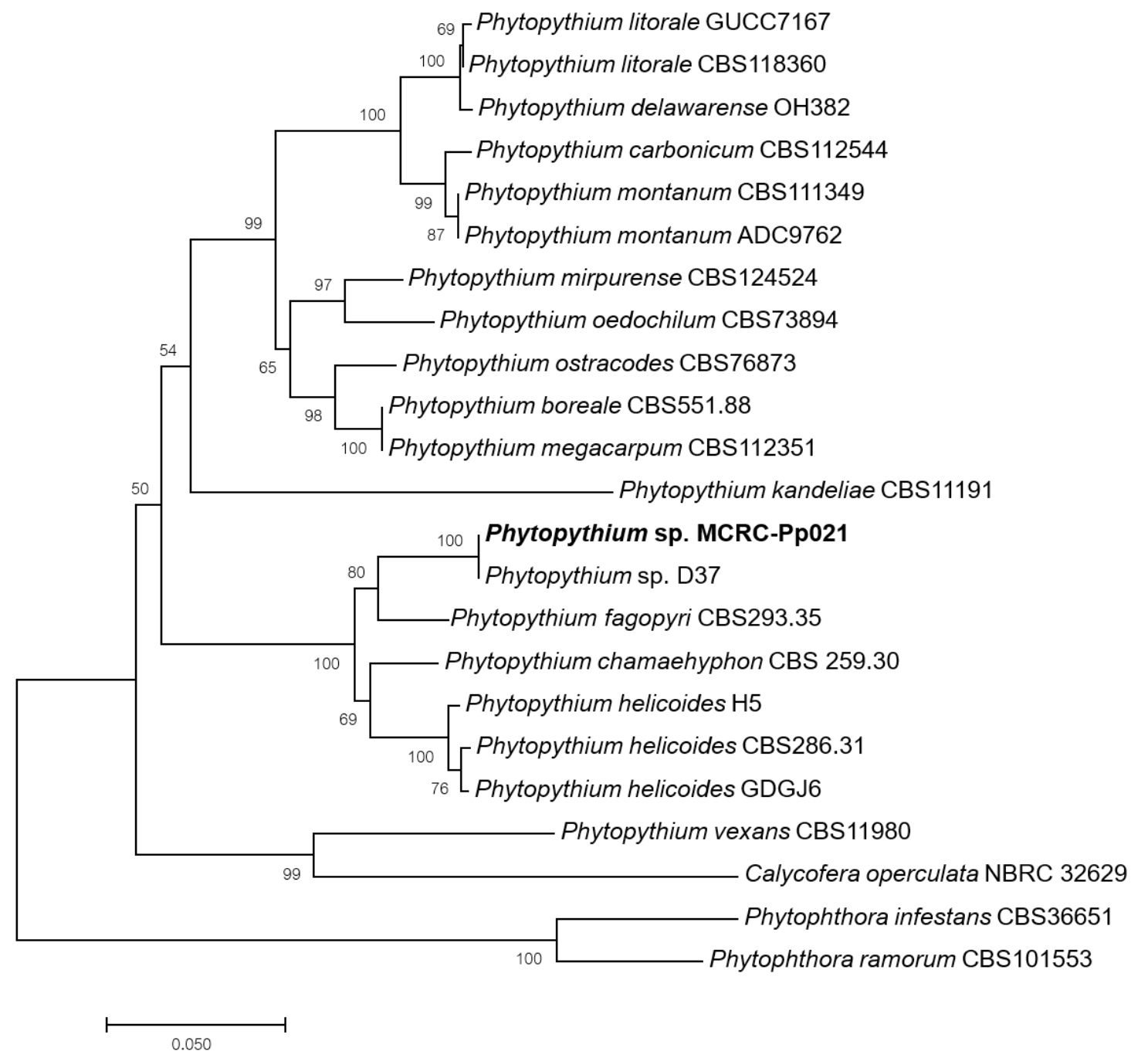

Fig. 4 - Neighbor-joining (NJ) consensus phylogenetic tree obtained from ITS rDNA sequences of Phytopythium sp. isolates using the MEGA 7.0 program. Bootstrap values are indicated on the branches (1000 replications)
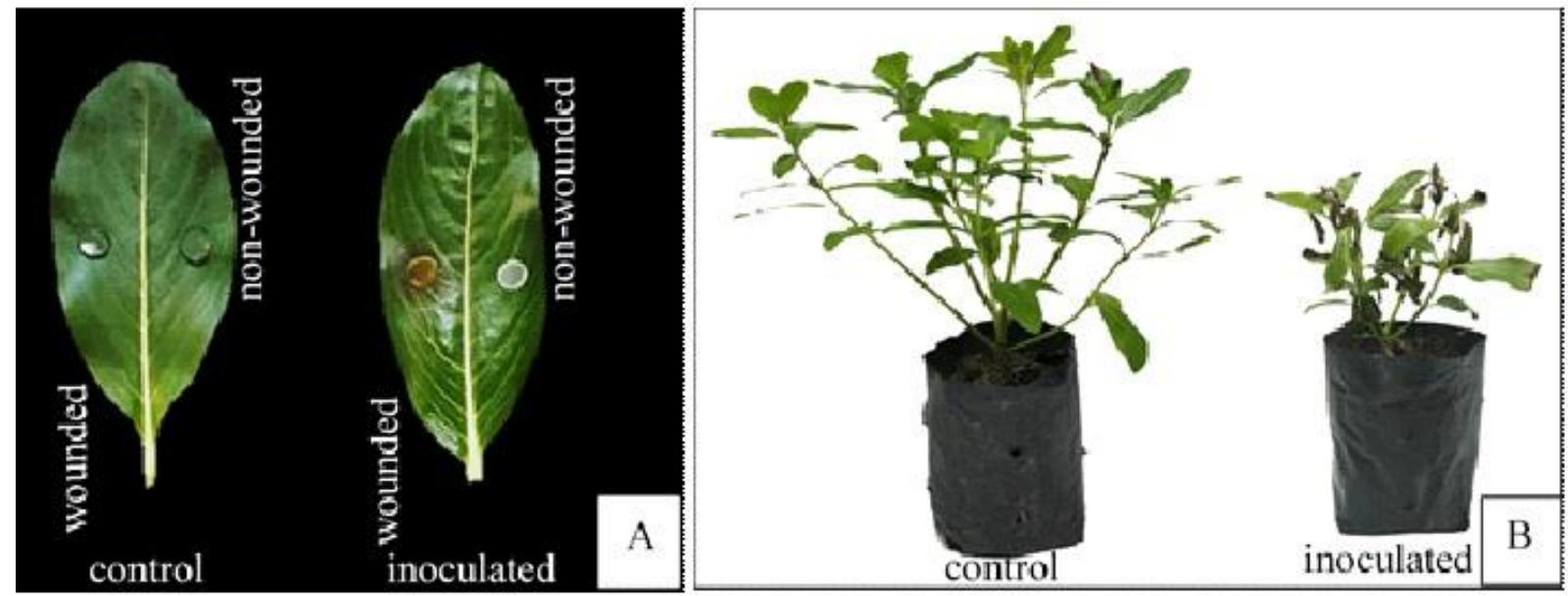

Fig. 5 - A The lesion on detached leaves $24 \mathrm{hr}$ after inoculation. B stem rot, crown rot and falling leaves 
At concentrations tested, dimethomorph was less effective, and inhibited mycelial growth of Phytopythium sp. isolate MCRC-Pp021 by 31.94-52.64\%, while fosetyl- aluminium inhibited mycelial growth by $39.31-100 \%$, phosphorous acid by $47.50-86.11 \%$, and metalaxyl by $83.05-$ $100 \%$ at $1000 \mathrm{ppm}$ (Table 2).

Table 2 Percent inhibition of mycelial growth of Phytopythium sp. isolate MCRC-Pp021 exposed to eight fungicides at different concentrations using the poison food assay.

\begin{tabular}{|c|c|c|c|c|c|c|c|c|}
\hline \multirow[t]{3}{*}{ Type } & \multirow[t]{3}{*}{ No. } & \multirow{3}{*}{$\begin{array}{l}\text { recommended } \\
\text { concentration } \\
(\mathbf{p p m})\end{array}$} & \multicolumn{6}{|c|}{ Inhibition of mycelial growth (\%) } \\
\hline & & & \multicolumn{6}{|c|}{ Concentration (ppm) } \\
\hline & & & $\mathbf{0}$ & 100 & 500 & 1,000 & $\mathbf{1 , 5 0 0}$ & 2,000 \\
\hline \multirow{3}{*}{$\begin{array}{l}\text { contact } \\
\text { fungicide }\end{array}$} & 1 & 1,200 & 0.00 & 100.00 & 100.00 & 100.00 & 100.00 & 100.00 \\
\hline & 2 & 1,750 & 0.00 & 100.00 & 100.00 & 100.00 & 100.00 & 100.00 \\
\hline & 3 & 200 & 0.00 & 100.00 & 100.00 & 100.00 & 100.00 & 100.00 \\
\hline \multirow{5}{*}{$\begin{array}{l}\text { systemic } \\
\text { fungicide }\end{array}$} & 4 & 500 & 0.00 & 31.94 & 37.50 & 39.44 & 40.28 & 52.64 \\
\hline & 5 & 2,000 & 0.00 & 39.31 & 66.39 & 76.67 & 88.89 & 100.00 \\
\hline & 6 & 100 & 0.00 & 47.50 & 71.25 & 78.74 & 80.28 & 86.11 \\
\hline & 7 & 187.5 & 0.00 & 100.00 & 100.00 & 100.00 & 100.00 & 100.00 \\
\hline & 8 & 125 & 0.00 & 83.05 & 90.56 & 100.00 & 100.00 & 100.00 \\
\hline
\end{tabular}

Note: $1=$ mancozeb, $2=$ propineb, $3=$ thiram, $4=$ dimethomorph, $5=$ fosetyl- aluminium, $6=$ phosphorous acid, $7=$ tridemorph, $8=$ metalaxyl

\section{Discussion}

The pathogen was isolated from soil in the rhizosphere of $C$. roseus showing root and stem rot disease. Isolated fungi infected detached leaves of $C$. roseus as well as the roots and crowns. The fungi were identified based on morphology and confirmed to be Phytopythium sp. by ITS rDNA sequencing analysis comparing to the reference sequences it was showed that Phytopythium sp. MCRC-Pp021 was distinct from other known species but similar to Phytopythium sp. D37 isolated from sediment sample in Virginia (Yang \& Hong 2016). It maybe conduced both of two strains are new species. However, more information on distinct characters of morphology are needed to study and sequence of another gene may be needed for molecular analysis. Moreover, it has never been reported on $C$. roseus in Thailand. To our knowledge, this present study represents the first report of Phytopythium sp. causing root and stem rot on C. roseus in Thailand.

Simultaneously, understanding the sensitivity of the pathogen to fungicides is necessary to provide farmers with a control strategy for root and stem rot of C. roseus. Phenylamides (PAs), carboxylic acid amides (CAA), phosphonates and dithiocarbamates are the major fungicide groups used to control the oomycete, fungus-like eukaryotic microorganisms (Gisi \& Sierotzki 2015). This study showed that dimethomorph and phosphorous acid seem to be less effective against $P p$. helicoides even used at recommended rates than mancozeb, propineb, thiram, fosetylaluminium, tridemorph and metalaxyl which exhibited high efficacy. This information might be useful to effectively control $C$. roseus root and stem rot in future. 


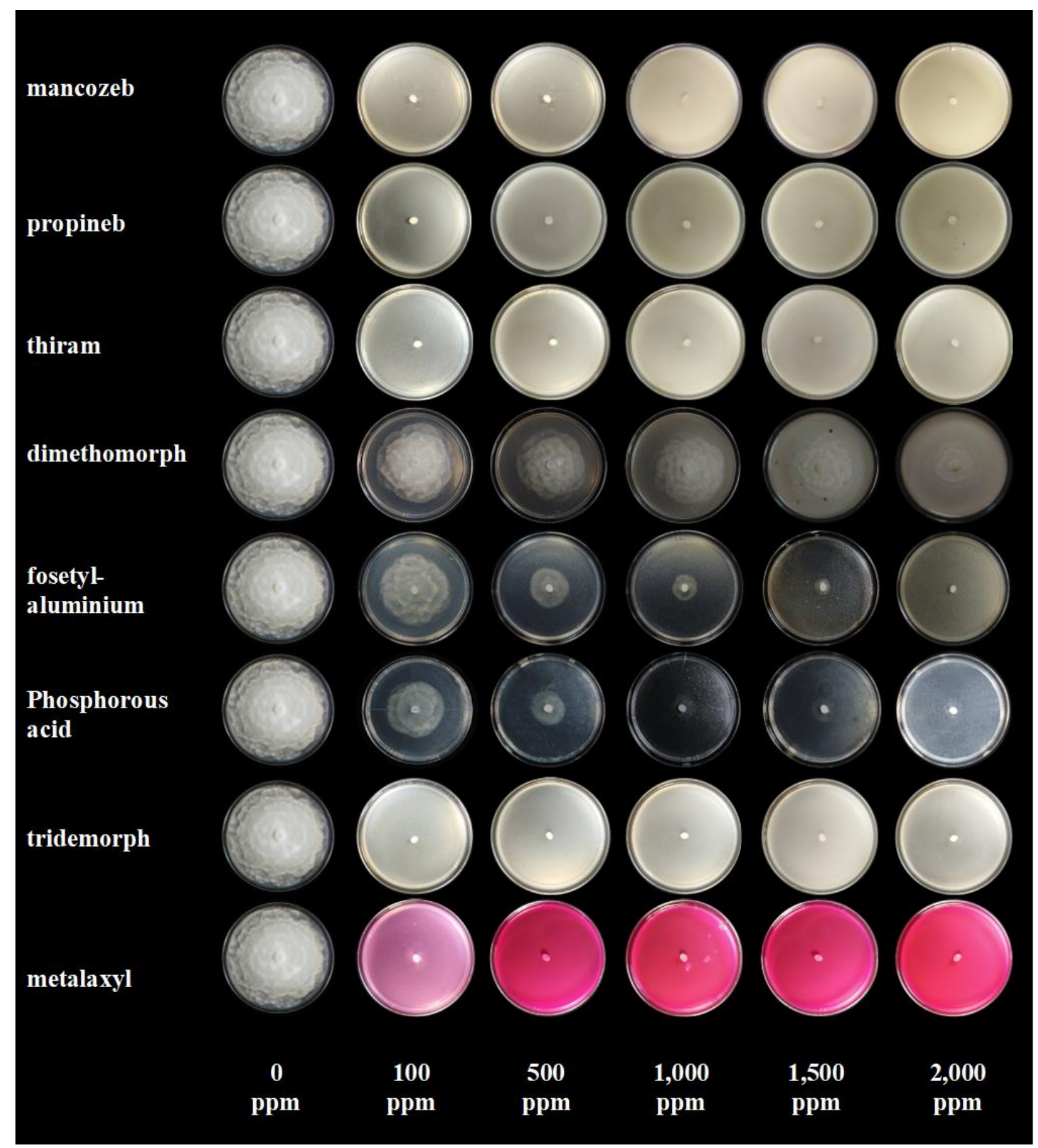

Fig. 6 - Percentage inhibition on of mycelial growth of Phytopythium sp. isolate MCRC-Pp021 exposed to eight fungicides at different concentrations using poison food.

\section{Acknowledgements}

This research is a part of a Ph.D. thesis. The authors wish to thank the Department of Entomology and Plant Pathology, Faculty of Agriculture, Chiang Mai University, Chiang Mai, Thailand.

\section{References}

Agrios GN. 1997 - Control of Plant Diseases. In Plant Pathology, 4th Edition, Academic Press, San Diego, 200-216. 
Bala K, Robideau GP, Lévesque A, de Cock AWAM et al. 2010 - Phytopythium Abad, de Cock, Bala, Robideau \& Levesque, gen. nov. and Phytopythium sindhum Lodhi, Shahzad \& Levesque, sp. nov.. Persoonia (Fungal Planet). 24:136-137.

Boari AJ, Cunha EM, Quadros AFF, Barreto RW, Fernandes AF. 2018 - First report of Phytopythium sp. causing storage root rot and foliage blight of Cassava in Brazil. Plant Disease 102, Published Online:19 Mar 2018. doi: 10.1094/PDIS-09-17-1449-P.

Chellemi DO, Mitchell DJ, Kannwischer-Mitchell ME, Rayside PA, Rosskopf EN. 2000 - Pythium spp. associated with bell pepper production in Florida. Plant Disease, 84, 1271-1274.

Chung WC, Huang JW, Sheu JC. 1998 - Fusarium root rot of periwinkle in Taiwan. Plant Protection Bulletin 40, 177-183.

de Cock AWAM, Lodhi AM, Rintoul TL, Bala K et al. 2015 - Phytopythium: molecular phylogeny and systematics. Persoonia34, 25-39.

Erwin DC, Ribeiro OK. 1996 - Phytophthora diseases worldwide. APS Press, St Paul, USA.

Garibaldi A, Bertetti D, Gullino ML. 2009 - First report of botrytis blight caused by Botrytis cinerea on Periwinkle (Catharanthus roseus) in Italy. Plant Disease 93, 554.

Gisi U, Sierotzki H. 2015 - Fungicide: Phenylamides, Ouinone Outside Inhibitors, and Carboxylic Acid Amides. In: Ishii H, Hollomon DW. (eds) Fungicide resistance in Plant Pathogens, Japan, Springer, 145-174.

Guha Roy S, Hong CX. 2008 - The first finding of Pythium root rot and leaf blight of elephant foot yam (Amorphophallus paeonifolius) in India. Plant Pathology 57, 369-369.

Hao W, Richardson PA, Hong CX. 2010 - Foliar blight of annual vinca (Catharanthus roseus) caused by Phytophthora tropicalis in Virginia. Plant Disease 94, 274.

Hong CX, Moorman GW. 2005 - Plant pathogens in irrigation water: challenges and opportunities. Critical Reviews in Plant Sciences 24, 189-208.

Intaparn P, Noireung P, Maumoon R, McGovern R et al. 2019 - First report of Pythium deliense causing root and crown rot on Catharanthus roseus in Thailand. Plant Pathology \& Quarantine 9, 239-247.

Kageyama K. 2014 - Molecular taxonomy and its application to ecological studies of Pythium species. Journal of General Plant Pathology 80, 26-314.

Kageyama K, Aoyagi T, Sunouchi R, Fukui H. 2002 - Root Rot of Miniature Roses Caused by Pythium helicoides. Journal of General Plant Pathology 68, 15-20

McMillan Jr RT, Garofalo JF. 2004 - Phytophthora parasitica wilt of new cultivars of Catharanthus roseus. Proceedings of the Florida State Horticultural Society 117, 316-317.

Nene YL, Thapliyal BW. 1979 - Fungicides in plant disease control. Oxford \& IBH Publisher house New Delhi, 425.

Saitou N, Nei M. 1987 - The Neighbor-Joining method: a new method for reconstructing phylogenetic trees. Molecular Biology and Evolution 4, 406-425.

Shang H, Chen J, Handelsman J, Goodman RM. 1999 - Behavior of Pythium torulosum zoospores during their interaction with tobacco roots and Bacillus cereus, Current Microbiology 38, 199-204.

Soytong K, Pongak W, Kasiolarn H. 2005 - Biological control of Thielaviopsis bud rot of Hyophorbe lagenicaulis in the field. Journal of Agricultural Technology 1, 235-245.

Tao YH, Zeng F, Ho HH, Wei JG et al. 2011 - Pythium vexans causing stem rot of Dendrobium in Yunnan Province, China. Journal of Phytopathology 159, 9-255.

Tsukiboshi T, Chikuo Y, Ito Y, Matsushita Y, Kageyama K. 2007 - Root and stem rot of chrysanthemum caused by five Pythium species in Japan. Journal of General Plant Pathology, 73, $293-296$.

Van der Plaats-Niterink AJ. 1981- Monograph of the genus Pythium. Studies in Mycology 21, 1244.

Vincent JM. 1947 - Distortion of fungal hyphae in the presence of certain inhibitors, Nature159, $180 \mathrm{p}$. 
Watanabe H, Taguchi Y, Hyakumachi M, Kageyama K. 2007 - Pythium and Phytophthora species associated with root and stem rots of kalanchoe. Journal General Plant Pathology 73, 81-88.

Weising K, Nybom H, Wolff K, Meyer W. 2000 - DNA fingerprinting in plants and fungi. CRC Press. 322p.

White TJ, Bruns T, Lee S, Taylor J. 1990 - Amplification and direct sequencing of fungal ribosomal RNA genes for phylogenetics. PCR Protocols: A Guide to Methods and Applications 18, 315-322.

Yang X, Hong CX. 2016 - Diversity and populations of Phytophthora, Phytopythium and Pythium species recovered from sediments in an agricultural run-off sedimentation reservoir. Plant Pathology 65, 1118-1125.

Yang X, Richardson PA, Olson HA, Hong CX. 2013 - Root and stem rot of begonia caused by Phytopythium helicoides in Virginia. Plant Disease 97, 1385-1385. 